Biljana Bogdanović ${ }^{1}$

Andrea Jovanović ${ }^{2}$

Tijana Lovre $^{3}$

Ana Nikolić 4

Narodna biblioteka Srbije ${ }^{5}$

\title{
INFORMACIONA PISMENOST KAO PREDUSLOV DOŽIVOTNOG UČENJA
}

\section{Sažetak}

Traganje za informacijama predstavlja jednu od najvažnijih potreba čoveka kako bi pronašao odgovore i došao do neophodnih saznanja. Pojavom pisma nastalo je umnožavanje informacija i njihovo memorisanje, dok se danas govori o takozvanoj eksploziji informacija čiji se broj eksponencijalno uvećava. Informaciona pismenost podrazumeva skup veština koje se odnose na pronalaženje informacija, njihovo kritičko procenjivanje i organizovanje kao i korišćenje koje poštuje etičke principe. Ona predstavlja osnovno pravo čoveka ali je i neophodan činilac u procesu sticanja znanja, a naročito je povezana sa doživotnim učenjem. Doživotno učenje omogućava razvoj pojedinaca ali i njihovog užeg i šireg okruženja. Šire posmatrano, ono doprinosi uspešnom suočavanju sa tehnološkim, ekonomskim i društvenim izazovima.

Ključne reči: informaciona pismenost, Veb 2.0, doživotno učenje, biblioteka

Traganje za informacijama predstavlja jednu od najvažnijih potreba čoveka kako bi pronašao odgovore i došao do neophodnih saznanja. Prema rečniku Matice srpske (2007), informacija se definiše kao podatak o nekome ili nečemu, obaveštenje. Ona sadrži element smisla koji se prenosi putem štampanog medija, električnog signala, zvučnog talasa itd. Njen cilj je saznanje, shvatanje smisla. Nastanak informacija opisuju dve glavne karakteristike:

1 biljana.bogdanovic@nb.rs

2 andrea.arsenovic@nb.rs

31tijana.lovre@nb.rs

4 ana.nikolic@nb.rs

5 Narodna biblioteka Srbije, Skerlićeva 1, Beograd 11000 
- Eksplozija kvantiteta informacija

- Implozija vremena potrebnog za komunikaciju informacija.

Broj informacija sve više raste, ali to je neophodno jer bez njih ne bi bilo istraživanja, nauka se ne bi razvijala. Informacija se stalno proizvodi i obnavlja, a značaj ima samo ako cirkuliše. One se šire putem komunikacije koja može biti pisana (formalna) i usmena (neformalna). Pisana komunikacija se odvija putem primarnih, sekundarnih i tercijarnih publikacija dok se usmena odnosi na izlaganje na seminarima, konferencijama, razgovorima itd. Da bi rezultati istraživanja do kojih je istraživač došao postali naučno priznati, odnosno kako bi došli do drugih istraživača čiji broj raste, oni moraju biti preneti u onoj formi koja omogućava njihovo razumevanje i korišćenje. Zato formalna komunikacija ima veću stabilnost od neformalne.

Informacije dovode do neophodnih saznanja te se dosta govori o veštini njihovog pronalaženja ali i potrebi kritičkog procenjivanja i etičkog korišćenja.

$U$ današnjoj elektronskoj eri one, prilagođavanjem i reorganizacijom, postaju informacioni centri, pa pored obrazovno vaspitne uloge imaju i novi koncept. One sada moraju odigrati ključnu ulogu u informacionom opismenjavanju posredstvom novih tehnologija zadržavajući pritom svoju prvobitnu ulogu. Današnje vreme, vreme „eksplozije“ informacija, koje počinje u drugoj polovini 20. veka je vrlo specifično. Pojava interneta i novih tehnologija, kao i servisa poput Biblioteke 2.0 izvršila je snažan uticaj na biblioteke i njihove tradicionalne službe i usluge. Bibliotekarstvo i bibliotekari su se našli pred velikim ispitom.

Biblioteke su oduvek bile i ostale važan činilac sociokulturnih procesa; oduvek su pratile promene $u$ društvu, a prenoseći znanje i informacije i uticale na te promene i bile njihov nosilac.

Postojalo je mnogo teorija kako će budućnost biblioteka izgledati, od kojih je najpesimističnija svakako ona da „revolucija koju je doneo internet, uz mogućnost neograničenog dostupa do informacija, učiniće nepotrebnim dalje postojanje javnih narodnih biblioteka. ${ }^{\prime 6}$ Ipak, ako imamo u vidu da je, kako tvrdi Majkl Gorman, predsednik američkog bibliotečkog udruženja, „veština čitanja i pisanja isto tako bitna za uspešno korišćenje računara koliko je bitna i za sve druge oblike komunikacije ${ }^{17}$ Najrealnija je teorija „aktivnog preobražaja tradicionalnih službi i usluga javnih biblioteka i njihov

6 Javne biblioteke i javno znanje / Željko Vučković. - Novi Sad : Biblioteka Matice srpske: Futura publikacije, 2003. - Str. 7.

7 Youth Services and Public Libraries / Susan E. Higgins. - Oxford : Chandos Publishing, 2007. - XIII, 153 str.: ilustr. ; 23 cm. - (Chandos Information Professional Series) - Str. 22. 
razvoj kao kulturnih i informacionih centara lokalne zajednice." ${ }^{8}$ Kao odgovor na eksploziju informacija nastao je koncept informacione pismenosti. „Informaciona pismenost je sposobnost da se locira, evaluira i efektno koristi tražena informacija. ${ }^{\text {" }}$ Uticajem današnje tehnologije i definisanjem termina poput Web 2.0 i Biblioteka 2.0 dolazimo do novog termina Informaciona pismenost 2.0. Definicija informacione pismenosti ostaje nepromenjena, samo se ostvaruje posredstvom različitih servisa kao što su blogovi, wiki sajtovi, mešap animacije, pa čak i preko igranja različitih igrica.

Informaciona pismenost 21. veka je skup mogućnosti i veština gde se slušna, vizuelna i digitalna pismenost preklapaju. Tako da danas imamo razne podvrste informacione pismenosti:

1. Digitalna pismenost - odnosi se na sposobnost čitanja i razumevanje hiperteksta ili multimedijskih tekstova, a uključuje razumevanje slika, zvukova i teksta dinamičkog nesekvencijalnog hiperteksta. lako većina autora o digitalnoj pismenosti govori u odnosu na informacije dostupne preko Interneta, koncept se odnosi i na digitalizovanu građu dostupnu u bibliotekama. Veštine obuhvaćene ovim terminom uključuju donošenje suda o online izvorima, pretraživanje Interneta, upravljanje multimedijalnom građom, komuniciranje preko mreže.

2. Medijska pismenost - obuhvata sposobnost razumevanja, korišćenja, analize i interpretacije poruka u svim oblicima masovnih medija i Internetu. Podstiče ljude da kritički misle i da razumevaju poruke koje se izražavaju slikom, zvukom i jezikom.

3. Vizuelna pismenost - bavi se razumevanjem kako da se proceni vrednost i kredibilitet slika. Predstavlja skup veština koji je značajno porastao u digitalnom okruženju.

Do sada se govorilo o pismenostima koje su pokušavale da komuniciraju sa Web 1.0 svetom statičkih dokumenata, ali u digitalnom okruženju koje raste neverovatnom brzinom. Web 2.0 je sve to promenio. Wiki stranice, Facebook, Youtube - suština je manje u tome šta nam nove tehnologije omogućavaju (lako istraživanje, priče od fotografija, filmovi) a

8 Javne biblioteke i javno znanje / Željko Vučković. - Novi Sad : Biblioteka Matice srpske: Futura publikacije, 2003. - Str. 7.

$9 \quad$ Uloga biblioteka u stvaranju informaciono pismenog pojedinca / Milica Matijević // Biblioteke i tinejdžeri: zbornik radova / ur: Elizabeta Georgiev i Nadica Kostić. - Pirot : Narodna biblioteka Pirot ; Dimitrovgrad : Narodna biblioteka „Detko Petrov“, 2012. - str. 154. 
više u tome da je vrsta ponašanja koje neguju drugačija od već navedenih modela pismenosti. Termin informaciona pismenost 2.0 polazi od viđenja veze između obrazovanja kao procesa koji uključuje stvaralaštvo, razmišljanje i kritičku svest i sve rastućom bitnošću informacione pismenosti.

Postoje različiti tipovi Informacione pismenosti 2.0:

1. Metapismenost - društveni mediji su uslovili informacionu pismenost da postane metapismenost kako bi omogućila različite vrste pismenosti. Smisao je da je zbog društvenih mreža informaciona pismenost postala obavezna za razumevanje svih drugih formi koje su prisutne online odnosno raznih drugih pismenosti.

2. Multimodalna pismenost - predstavlja sintezu brojnih modela komunikacije koja dovodi do transformacije pojedinačnih načina proizvodeći nova ili višebrojna značenja.

3. Transmedijska pismenost - transemdijalni pristup prepoznaje potrebu za učenjem komunikacije u svim oblicima: ne samo reči već slika, muzike i filma. Transmedijalnost je o drugačijim i različitim medijskim sistemima i njihovoj mogućnostida se kreću kroz socijalno okruženje.

4. Transpismenost - mogućnost za čitanjem, pisanjem i interakcijom kroz različite platforme, alate i medije. Osoba bi morala prvo biti informaciono pismena da bi bila transpismena. Jedna od kritika transpismenosti jeste to što bibliotekari usvajaju ovaj termin pre nego što znaju njegovo značenje.

\section{Informaciono učenje}

Ovaj koncept je još jedan pristup informacione pismenosti koji ide dalje od standardnih okvira i pristupa u sprezi sa veštinama i sposobnostima, i više prema korišćenju informacija u svetu Weba 2.0 za povezivanje sa akademskim ili profesionalnim sadržajima ili praksama u okviru određene sfere izučavanja. Ovo se čini slično transliterarnom pristupu, koji se nadovezuje na prethodno znanje i podstiče rešavanje problema u okviru određene discipline ili konteksta, dok unapređuje učenikovu fleksibilnost i samopouzdanje da koristi informacija u okruženju gde su informacije promenljive. Web 2.0 je savršen za ovu razmenu i komunikaciju, pošto može da pospeši radoznalost i kreativnost u poznatim 2.0 okruženjima.

Postoji mnogo različitih pismenosti koje se smenjuju po bitnosti, u zavisnosti od forme i nivoa aktivnosti, društvenog diskursa i predmeta 
discipline. Web 2.0 je uticao na ovo i doneo nam tehničku mogućnost da stvaramo, delimo i povezujemo se na toliko novih načina. Još uvek nismo stigli do kraja ovog razvoja i verovatnije je da smo tek videli samo početak. Pismenosti su povezane i većina njih sadrži neku vrstu kritičkog razmišljanja i razvijanja skepticizma u svom jezgru. To je ono što bi trebalo da bude osnova informacione pismenosti u bliskoj budućnosti. Radi pogodnosti, mi ćemo nastaviti to da zovemo informacionom pismenošću, ne zato što nam se tako dopada, već zato što je to najbolji naziv koji imamo.

\section{Doživotno učenje}

Za uspeh i napredak pojedinaca, organizacija i država u apsolutnom informacijskom društvu današnjice, ključna je veza između informacione pismenosti i doživotnog učenja. Oba koncepta uslovljena su motivacijom i ciljevima samog pojedinca i ne zavise direktno od podrške drugih pojedinaca i organizacija, a omogućavaju samoosposobljavanje i samoostvarivanje. Neko, naravno, može samo u određenom životnom razdoblju težiti informacionom opismenjavanju, a neko drugi može težiti doživotnom učenju iako nije informaciono pismen. Međutim, ovde govorimo o maksimalnom potencijalu pojedinca da "nauči kako da uči" što je moguće samo međusobnim podržavanjem ova dva koncepta.

Koncept doživotnog učenja (Lifelong Learning - LLL) odnosi se na ideju učenje koje traje čitavog života. Osnovna zamisao je da treba da postoji obrazovni sistem, koji će, u svakom trenutku, svakom pojedincu, bez obzira na životnu dob ili profesionalni status, pružiti mogućnost da ovlada novim, raznovrsnim i korisnim znanjima. Doživotno učenje, kao intenzivan rad na razvoju ljudskih potencijala, je postalo neophodan uslov za ostvarivanje dobrobiti savremenog društva.

Doživotno učenje predstavlja proces usvajanja znanja koji se odvija na stalnoj osnovi, a u cilju unapređivanja znanja, veština i sposobnosti. Podrazumeva sve oblike usvajanja znanja, kako kroz formalno tako i kroz neformalno i informalno učenje, i odvija se u različitim uslovima. Doživotno učenje ima dve dimenzije: vremensku koja podrazumeva da "čovek uči dok je živ" i prostornu, koja podrazumeva da se ne uči samo u obrazovnim ustanovama, već i na svakom mestu i u svim životnim situacijama.

Evropski parlament i Savet Evrope su 2006. godine ustanovili Ključne kompetencije za doživotno učenje ${ }^{10}$, a to su: komunikacija na maternjem

10 http://publications.europa.eu/resource/cellar/89e165de-b214-4013-81c6c8a12e52330b.0019.02/DOC_1 (preuzeto 10.06.2017.) 
jeziku, komunikacija na stranim jezicima, matematičke kompetencije i osnovne naučne i tehničke kompetencije, digitalne kompetencije, učenje kako se uči, društvene i građanske kompetencije, inicijativnost i smisao za preduzetništvo i kulturna svest i izražavanje.

Izjava o informacionoj pismenosti i doživotnom učenju (The Alexandria Proclamation on Information Literacy and Lifelong Learning ${ }^{11}$ doneta je 2005. godine na međunarodnoj konferenciji koja je održana u biblioteci Aleksandrina u Egiptu. U ovoj Izjavi navodi se da su informaciona pismenost i doživotno učenje svetionici informacionog društva koji osvetljavaju puteve razvoja društva, apeluje se na vlade i međuvladine organizacije da promovišu informacionu pismenost i učenje za celi život.

IFLA je 2006. godine donela Smernice za informacionu pismenost $u$ doživotnom učenju gde se predstavljaju mogućnosti informacionog opismenjavanja koje su tesno povezane sa konceptom celoživotnog učenja i informacione pismenosti.

Dok je informaciona pismenost skup veština koje se mogu naučiti, doživotno učenje je pozitivna navika koja se mora steći, uz zauzimanje pozitivnog stava. Korisni preduslovi doživotnog učenja su želja za promenom, znatiželja i želja za znanjem, kao i okrenutost sebi, metakognitivna svest i sklonost ka doživotnom učenju.

Doživotno učenje predstavlja prioritet za one zemlje koje su sagledale značaj ovog procesa za ukupan društveni prosperitet. Dugoročnim planovima i programima ove države nastoje da stvore uslove da informaciona pismenost i doživotno učenje postanu stvarnost za pojedince, ali i za društvenu zajednicu. Ipak, primena ovog principa u praksi je mukotrpan i komplikovan posao. Tradicionalne institucije obrazovanja u svetlu novih potreba koje ima društvo spoznaju da se učenje mora obavljati u različitim kontekstima, a potrebno je da načini učenja budu fleksibilniji i da se radi na razvoju mešovitog učenja, prakse u okviru različitih kompanija, učenja na daljinu, elektronskog učenja, učenja kroz rad i slično.

$\mathrm{U}$ društvu celoživotnog učenja, biblioteke postaju centri koji povezuju učenje, bilo formalne ili neformalne vrste, sa globalnim sredstvima informisanja i zato će biti vrlo značajne u razvoju budućih sistema doživotnog učenja. Promena načina usvajanja znanja znači veće korišćenje bibliotečkih resursa, uključujući štampane i elektronske izvore. Iz tog

11 https://www.ifla.org/files/assets/wsis/Documents/BeaconlnfSoc-rs.pdf (preuzeto 12.06.2017.) 
razloga biblioteke moraju da obezbede slobodan pristup informacijama, moraju imati aktuelne fondove i savremenu opremu, kako bi u vremenu novih tehnologija zadovoljile potrebe svojih korisnika i ostale važni centri za doživotno učenje. Biblioteke razvijaju e-učenje i povećavaju digitalnu pismenost svojih korisnika, čime pružaju mogućnosti obrazovanja i učenja svima - svim uzrastima ali i svim slojevima stanovništva. Podstiču doživotno učenje kroz promociju čitanja i pismenosti, ali i kroz pristup savremenim medijima kao izvorima informacija.

Radeći na poslovima opismenjavanja drugih i bibliotekari dolaze u poziciju da se moraju neprekidno samoobrazovati i prolaziti kroz najrazličitije vidove doživotnog obrazovanja. Kako bi se postigli bolji rezultati i kako bi mogli da prate promene koje nastaju svakodnevno u čitavom našem okruženju, bibliotečki radnici moraju neprestano da uče i da usavršavaju metode i tehnike rada. Kontinuirano obrazovanje bibliotekara počinje nakon završetka formalnog školovanja i traje tokom čitavog života kroz različite vidove usavršavanja: kurseve, seminare, radionice, konferencije koje im omogućavaju stalno napredovanje u radu. Dobra informisanost i obučenost bibliotekara korak je napred ka bolje informisanim korisnicima, a informaciono pismen bibliotekar preduslov je za informaciono opismenjavanje svih onih koji koriste usluge biblioteke u kojoj radi.

\section{Literatura i izvori}

Brković, Mirjana. „Informaciona pismenost, doživotno učenje i savremeno bibliotekarstvo“. U Informaciona pismenost i doživotno učenje. Urednici Aleksandra Vraneš, Ljiljana Marković i Gven Aleksandar, 79-88. Beograd: Filološki fakultet Univerziteta; Bibliotekarsko društvo Srbije; Emporia univerzitet, 2008.

Gazivoda, Pavle. Društvene promene $i$ doživotno obrazovanje. Podgorica: Zavod za udžbenike i nastavna sredstva, 2004.

Godwin, Peter and Jo Parker, ed. Information Literacy Beyond Library 2.0. London: Facet Publishing, 2012.

IFLA/UNESCO Smernice za razvoj javnih biblioteka. Beograd: Narodna biblioteka Srbije; Biblioteka grada Beograda, 2005.

Jesús, Lau. Smjernice za informacijsku pismenost i cjeloživotno učenje: završna verzija. Zagreb: Hrvatsko knjižničarsko društvo, 2014.

Crawford, John C. i Christine Irving. Information Literacy and Lifelong Learning. Oxford: Chandos Publishing, 2013.

Maksimović, Iskra. „Celoživotno učenje: ključne kompetencije“. Nasleđe 21 (2012): 231-246. 
Maštrović, Tihomir, Aleksandra Horovac, Dijana Machala, Ana Barbarić, Marion Huckle, Tatjana Nebesny i Daniela Živković. Cjeloživotno učenje knjižničara: ishodi učenja i fleksibilnost. Zagreb: Nacionalna i sveučilišna knjižnica, 2009.

Stojanović, Aleksandar. Informacione tehnologije: računarska pismenost. Beograd: Beogradska poslovna škola - Visoka škola strukovnih studija, 2014.

Susie, Andretta. Information literacy: a practitioner's guide. Oxford: Chandos, 2005.

Weingald, Darlene E. „Describing the elephant: what is continuing professional education?“. http://www.ifla.org/IV/ifla65/papers/089-104e.htm (преузето 17.06.2017).

Vučković, Željko. Javne biblioteke i javno znanje. Novi Sad : Biblioteka Matice srpske, 2003. Higgins, Susan E. Youth Services and Public Libraries. Oxford : Chandos Publishing, 2007.

Matijević, Milica. Uloga biblioteke u stvaranju informaciono pismenog pojedinca. U Biblioteke i tinejdžeri. Urednici Elizabeta Georgiev i Nadica Kostić. 154. Pirot : Narodna biblioteka Pirot, Dimitrovgrad : Narodna biblioteka "Detko Petrov", 2012.

\section{Biljana Bogdanović Andrea Jovanović Tijana Lovre Ana Nikolić}

\section{INFORMATION LITERACY AS A PREREQUISITE FOR LIFELONG LEARNING}

\section{Summary}

The search for information is one of the most important needs of a man on his path to finding answers and obtaining necessary knowledge. With the invention of writing systems, it became possible to store and multiply information, and today there are talks about the information explosion, as the amount of stored data grows exponentially. Information literacy implies a combination of skills needed for finding information, critically evaluating it, organizing it, as well as using it within ethical principles. It is a basic human right, but also a necessary element for the process of obtaining knowledge, especially important in terms of lifelong learning. Lifelong learning enables the development of an individual, as well as his close and broad community. In essence, it helps people face technological, economic and social challenges. The library has an important role in achieving this goal by providing support to its users.

Keywords: information, information literacy, Web 2.0, lifelong learning, library 